\title{
Celebrity disclosures and information seeking: the case of Angelina Jolie
}

\author{
Robin H. Juthe, $\mathrm{MPH}^{1}$, Amber Zaharchuk, $\mathrm{MBA}^{2}$ and Catharine Wang, PhD, MSc ${ }^{3}$
}

Purpose: On 14 May 2013, actress Angelina Jolie disclosed that she had a BRCA1 mutation and underwent a prophylactic bilateral mastectomy. This study documents the impact of her disclosure on information-seeking behavior, specifically that regarding online genetics and risk reduction resources available from the National Cancer Institute.

Methods: Using Adobe Analytics, daily page views for 11 resources were tracked from 23 April 2013 through 25 June 2013. Usage data were also obtained for four resources over a 2 -year period (20122013). Source of referral that viewers used to locate a specific resource was also examined.

Results: There was a dramatic and immediate increase in traffic to the National Cancer Institute's online resources. The Preventive

\section{INTRODUCTION}

On 14 May 2013, acclaimed actress and philanthropist Angelina Jolie published an op-ed piece in The New York Times in which she shared her decision to undergo a prophylactic bilateral mastectomy after learning that she had a deleterious BRCA1 mutation. ${ }^{1}$ Jolie's announcement spawned a sudden and profound media response, ${ }^{2-6}$ with her face adorning the cover of both Time and People in the following weeks and much reference to the "Angelina effect." The announcement was reported as the most blogged about medical topic in the past 5 years. ${ }^{7}$ Referrals to cancer genetics clinics increased by twofold to threefold after Jolie's disclosure, ${ }^{3,8-14}$ with some clinics pleading for additional resources. ${ }^{15}$

Increases in information seeking have been observed after health-related disclosures by other celebrities. ${ }^{16-23}$ In the case of Jolie, an increase in information-seeking behavior is likely to be felt by the genetics community as other health professionals and the public attempt to learn more about the BRCA genes, hereditary cancers, and strategies for reducing inherited cancer risk. Conceptually, celebrity disclosures can have further downstream effects, including earlier detection of disease and reduced disease overall. ${ }^{24}$ Thus, an increased awareness of hereditary breast and ovarian cancer achieved through greater information seeking about the disease could lead to earlier identification of high-risk individuals who might benefit from intervention.
Mastectomy fact sheet received 69,225 page views on May 14, representing a 795-fold increase as compared with the previous Tuesday. A fivefold increase in page views was observed for the PDQ Genetics of Breast and Ovarian Cancer summary in the same time frame. A substantial increase, from 0 to $49 \%$, was seen in referrals from news outlets to four resources from 7 May to 14 May.

Conclusion: Celebrity disclosures can dramatically influence online information-seeking behaviors. Efforts to capitalize on these disclosures to ensure easy access to accurate information are warranted.

Genet Med advance online publication 23 October 2014

Key Words: BRCA; celebrity disclosure; hereditary breast and ovarian cancer; information seeking; preventive mastectomy

Documentation of the effect of Jolie's disclosure on information-seeking behavior has been limited to the news stories that subsequently ensued. ${ }^{4,25-28}$ To our knowledge, only one report to date has attempted to systematically measure the effect of Jolie's announcement on information-seeking behavior. ${ }^{28}$ This report examined online information seeking surrounding two topics: mastectomy and BRCA. In the present study, we sought to systematically quantify the effect of Jolie's disclosure on information seeking by measuring user engagement with a variety of cancer genetics and risk reduction resources available on the National Cancer Institute (NCI) website.

NCI's Office of Communications and Education maintains resources for both health professionals and the public. Resources for health professionals are written at a technical level that assumes an expertise in medicine. Resources for the public are written in less technical language and often include illustrations and glossary links to explain complex terms. NCI's Physician Data Query (PDQ) cancer genetics information summaries for health professionals were examined in this study, as were NCI's fact sheets and Cancer Genetics Services Directory, both of which are available to the public. A list of the specific resources included in this study is presented in Table 1, along with additional background for each type of resource.

The specific objectives of this study were to (i) identify the immediate impact of Jolie's disclosure on Internet traffic to

${ }^{1}$ Office of Communications and Education, National Cancer Institute, Bethesda, Maryland, USA; ${ }^{2}$ iDoxSolutions, Bethesda, Maryland, USA; ${ }^{3}$ Department of Community Health Sciences, Boston University School of Public Health, Boston, Massachusetts, USA. Correspondence: Robin H. Juthe (robin.juthe@nih.gov) 
Table $1 \mathrm{NCl}$ resources

\begin{tabular}{|c|c|c|}
\hline Title & Resource type & Audience \\
\hline \multicolumn{3}{|l|}{ Breast cancer information } \\
\hline $\begin{array}{l}\text { BRCA1 and BRCA2: Cancer } \\
\text { Risk and Genetic Testing }\end{array}$ & Fact sheet ${ }^{\mathrm{a}}$ & Public \\
\hline $\begin{array}{l}\text { Breast Reconstruction After } \\
\text { Mastectomy }\end{array}$ & Fact sheet & Public \\
\hline Preventive Mastectomy ${ }^{b}$ & Fact sheet & Public \\
\hline $\begin{array}{l}\text { PDQ Genetics of Breast and } \\
\text { Ovarian Cancer }\end{array}$ & PDQ summaryc & $\begin{array}{l}\text { Health } \\
\text { professionals }\end{array}$ \\
\hline \multicolumn{3}{|l|}{ Other cancer information } \\
\hline $\begin{array}{l}\text { Cancer Genetics Services } \\
\text { Directory }\end{array}$ & $\begin{array}{l}\text { Directory of genetics } \\
\text { professionals }\end{array}$ & Public \\
\hline $\begin{array}{l}\text { Genetic Testing for } \\
\text { Hereditary Cancer Syndromes }\end{array}$ & Fact sheet & Public \\
\hline $\begin{array}{l}\text { PDQ Cancer Genetics } \\
\text { Overview }\end{array}$ & PDQ summary & $\begin{array}{l}\text { Health } \\
\text { professionals }\end{array}$ \\
\hline $\begin{array}{l}\text { PDQ Cancer Genetics Risk } \\
\text { Assessment and Counseling }\end{array}$ & PDQ summary & $\begin{array}{l}\text { Health } \\
\text { professionals }\end{array}$ \\
\hline $\begin{array}{l}\text { PDQ Genetics of Colorectal } \\
\text { Cancer }\end{array}$ & PDQ summary & $\begin{array}{l}\text { Health } \\
\text { professionals }\end{array}$ \\
\hline $\begin{array}{l}\text { PDQ Genetics of Prostate } \\
\text { Cancer }\end{array}$ & PDQ summary & $\begin{array}{l}\text { Health } \\
\text { professionals }\end{array}$ \\
\hline PDQ Genetics of Skin Cancer & PDQ summary & $\begin{array}{l}\text { Health } \\
\text { professionals }\end{array}$ \\
\hline
\end{tabular}

$\mathrm{NCl}$, National Cancer Institute; PDQ, Physician Data Query.

aFact sheets are Web documents that provide information on cancer topics in a question-and-answer format for the public. Fact sheets are developed by $\mathrm{NCl}$ science writers and edited and approved by $\mathrm{NCl}$ experts in each topic. The fact sheet collection can be accessed at http://www.cancer.gov/cancertopics/

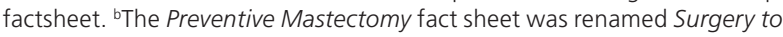
Reduce the Risk of Breast Cancer in October 2013. 'PDQ cancer genetics information summaries are evidence-based summaries written for health professionals about risk assessment, screening, and treatment of inherited cancer syndromes and topics related to genetic testing, genetic counseling, and psychosocial factors. The summaries are written and updated by expert members of the PDQ Cancer Genetics Editorial Board, which is editorially independent of the $\mathrm{NCl}$. The PDQ cancer genetics summaries can be accessed at http://www. cancer.gov/cancertopics/pdq/genetics. ${ }^{\mathrm{D} T}$ The Cancer Genetics Services Directory is an online listing of individuals who provide genetic services, including cancer risk assessment, genetic counseling, and genetic susceptibility testing. This directory is provided for the public. To be included in the directory, individuals must be licensed, board certified, or board eligible in their profession and meet other specific criteria. The Cancer Genetics Services Directory can be at accessed at http://www.cancer.gov/cancertopics/genetics/directory.

selected NCI cancer genetics and risk reduction resources, including fact sheets, the Cancer Genetics Services Directory, and the PDQ cancer genetics summaries; (ii) detail long-term trends of information seeking regarding these resources; and (iii) determine the source by which individuals were referred to this information.

\section{Content identification}

\section{MATERIALS AND METHODS}

Table 1 provides a list of the online cancer genetics and risk reduction resources maintained by NCI's Office of Communications and Education that were examined in this study. Resources are grouped into those specific to breast cancer and those covering other cancer genetics information.

The PDQ genetics summaries on colorectal, prostate, and skin cancers were included in this analysis to determine whether there was an effect on Internet traffic to genetics resources for cancer types other than breast.

\section{Data collection}

Internet traffic to these resources was measured using Adobe Analytics. Adobe Analytics is an integrated digital media analytics platform that uses page tagging to collect data; a small block of JavaScript code is added to each HTML page, which sets the values for analytic data. Each time an Internet page is accessed, the JavaScript code sends data to the Adobe Data Center, where the data are stored in repositories for reporting and analysis. Page view and referral reports were used to capture information about daily and monthly page views for these resources and the sources of referral by which the resources were located.

\section{Data analysis}

A "page view" was defined as the number of times a Web page was opened or refreshed. A "referral" from an external Web page (outside NCI's main website) was counted if the source had a link that led readers directly to the NCI resource. For these analyses, all Internet Protocol addresses for NCI offices and NCI's Cancer Information Service were filtered out, as were nonhuman "visitors" (e.g., spiders, bots).

To identify the immediate impact of Jolie's disclosure, the magnitude of the change in page views was assessed for each resource from Tuesday, 7 May 2013 (1 week before the op-ed piece appeared) through Tuesday, 14 May 2013 (the date it was published). In addition, the number of page views for each resource was examined over a 9-week period (23 April 2013 through 25 June 2013), including 3 weeks before and 6 weeks after the op-ed piece appeared. Daily page view data are presented for each Tuesday during this time period.

Usage data of NCI's breast cancer resources that were collected over 2 years (1 January 2012 through 31 December 2013) are reported to examine long-term information-seeking trends before and after Jolie's disclosure.

To determine how individuals located the breast cancer information and to understand how the source of referrals changed over time, referral data were collected for a 9-week period (23 April 2013 through 25 June 2013). Referral sources were classified into the following categories: (i) search engines, including websites that are primarily used to identify Web content that is relevant to a user's typed entry; (ii) news outlets, including traditional news websites and entertainment or celebrity news websites; and (iii) other referrals, including other NCI websites, typed URLs, bookmarked links, and other websites. Viewers who came to these resources from other Web pages on NCI's main website were not counted in the referral totals.

\section{RESULTS}

\section{Immediate impact and short-term trends}

There was a dramatic increase in Internet traffic to NCI's online resources on Tuesday, 14 May 2013 (Table 2). Among breast cancer resources written for the public, the Preventive 
Table 2 Daily page views of $\mathrm{NCl}$ cancer information resources, April-June 2013

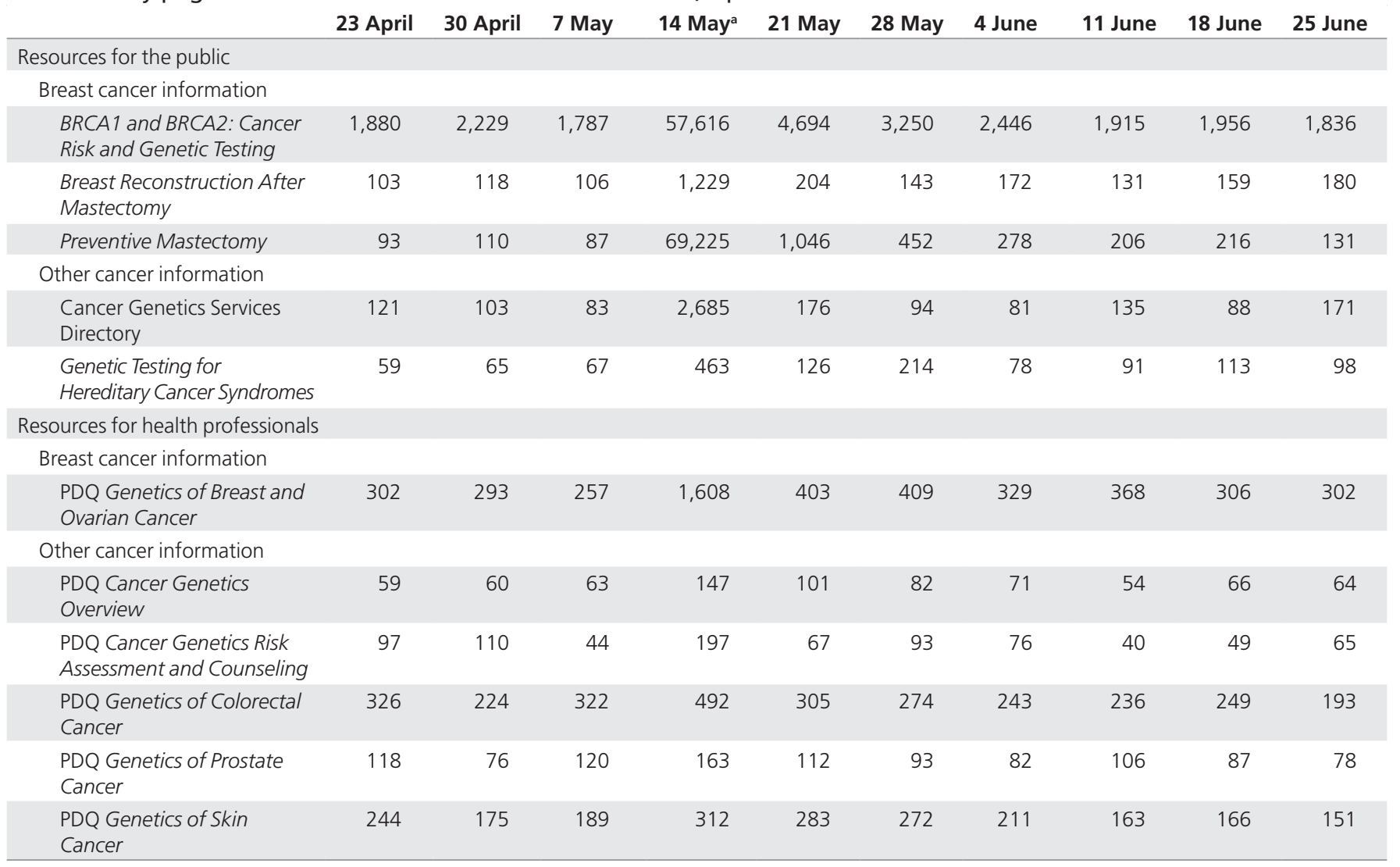

$\mathrm{NCl}$, National Cancer Institute; PDQ, Physician Data Query.

aAngelina Jolie's op-ed piece, "My Medical Choice," was published in The New York Times.

Mastectomy fact sheet saw the largest spike, with 69,225 page views on 14 May, representing a 795-fold increase compared with the number of page views (87) on the previous Tuesday. The BRCA1 and BRCA2: Cancer Risk and Genetic Testing fact sheet had a 31-fold increase in page views on 14 May $(57,616$ page views) as compared with 7 May (1,787 page views). An 11 -fold increase was observed for the Breast Reconstruction After Mastectomy fact sheet during the same time frame (1,229 vs. 106 page views).

Several other resources for the public saw substantial increases in page views. The Cancer Genetics Services Directory had 2,685 page views on 14 May 2013, representing a 31-fold increase over the number of page views (83) on 7 May 2013. The Genetic Testing for Hereditary Cancer Syndromes fact sheet saw a sixfold increase in page views during the same time frame (463 vs. 67 page views).

NCI's PDQ cancer genetics summaries for health professionals also experienced an increase in Internet traffic on the date Jolie's op-ed piece appeared. A fivefold increase in page views was observed for the PDQ Genetics of Breast and Ovarian Cancer summary on 14 May (1,608 page views) as compared with the previous week (257 page views). Other PDQ cancer genetics summaries not focused specifically on breast cancer also experienced increases in page views on 14 May as compared with the previous Tuesday. For example, the PDQ Cancer Genetics Risk Assessment and Counseling summary had a 3.5-fold increase in page views as compared with the previous week (197 vs. 44 page views). Other summaries with notable increases included the PDQ Genetics of Skin Cancer summary, which experienced a $65 \%$ increase in page views on 14 May as compared with 7 May, and the PDQ Genetics of Colorectal Cancer summary, which had a 53\% increase in page views during the same time frame.

Daily traffic to these resources remained elevated over the 6 weeks after the publication of Jolie's op-ed piece; it gradually returned to pre-Jolie levels toward the end of June.

\section{Long-term trends}

Figure 1 summarizes monthly page views for the breast cancer resources from January 2012 to December 2013. These data revealed a consistent pattern, with the largest number of page views occurring in May 2013, when Jolie's op-ed piece appeared. Each resource also saw an increase in page views in October 2012 and October 2013 (Breast Cancer Awareness Month in the United States), although these increases were much smaller than the peak observed in May 2013.

The Preventive Mastectomy fact sheet (Figure 1a) received an average of 2,667 page views each month from January 2012 
a

Preventive Mastectomy fact sheet:

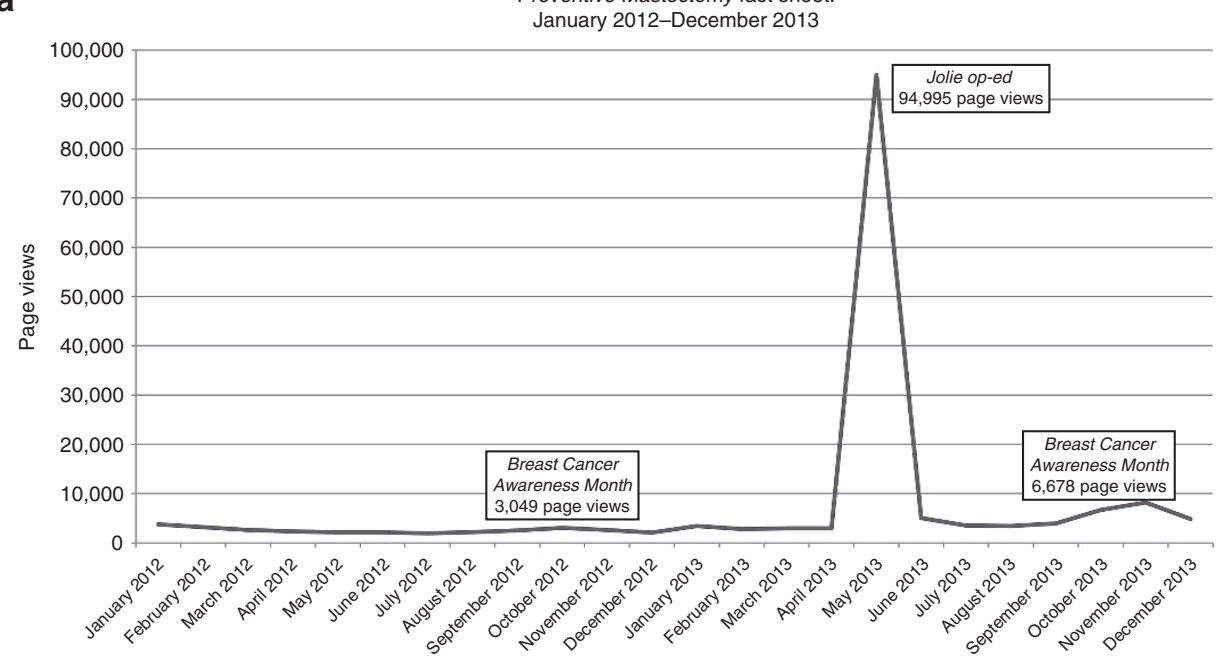

b

BRCA1 \& BRCA2: Cancer Risk \& Genetic Testing fact sheet:

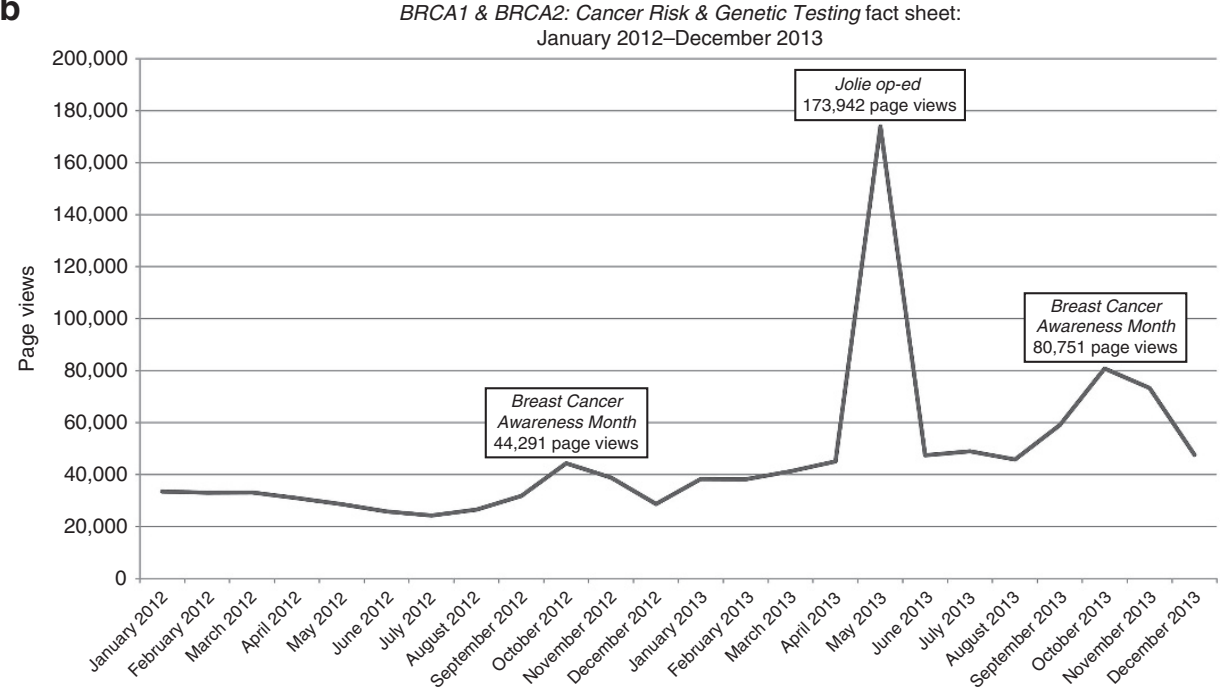

C

PDQ Genetics of Breast and Ovarian Cancer summary:

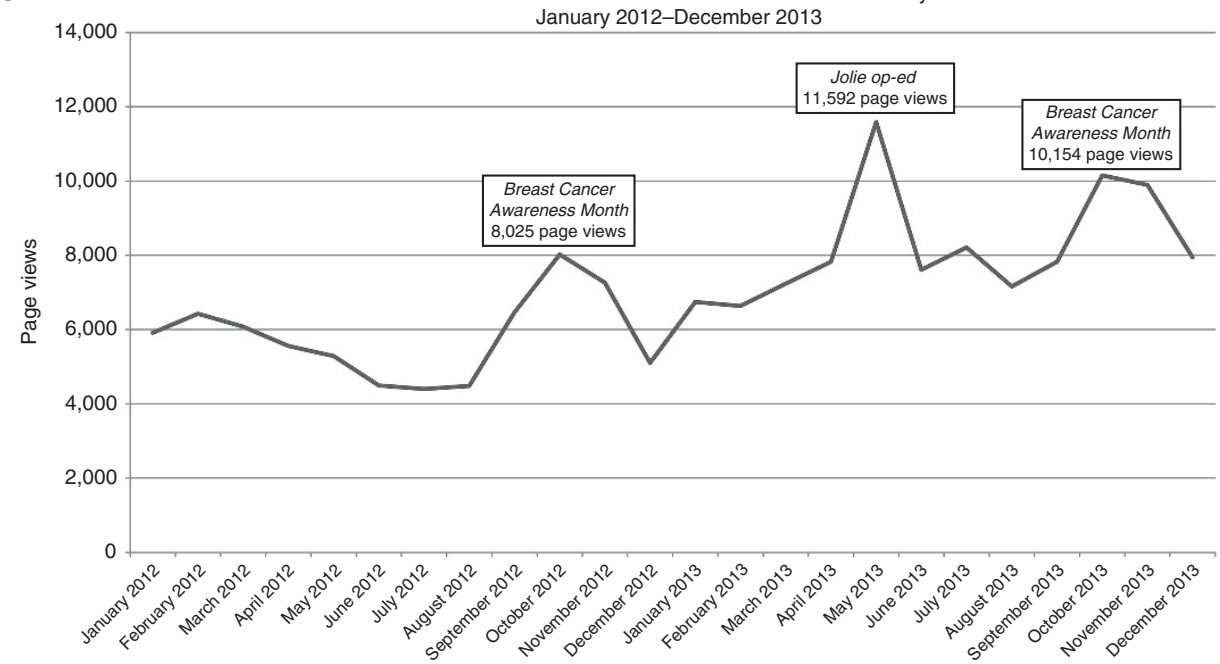

Figure 1 Monthly page views of National Cancer Institute's breast cancer resources from January 2012 through December 2013. Includes (a) the Preventive Mastectomy fact sheet for the public; (b) the BRCA1 and BRCA2: Cancer Risk and Genetic Testing fact sheet for the public; and (c) the Physician Data Query (PDQ) Genetics of Breast and Ovarian Cancer summary for health professionals. These trends reveal the magnitude of the increase in page views during May 2013, when Jolie's op-ed piece was published. 
through April 2013. However, the 2-year trend of monthly page views for this resource illustrates the magnitude of the increase in page views in May 2013, when Jolie's op-ed piece was published (94,995 page views). The figure also illustrates a sudden post-Jolie decrease in the monthly page views to 5,031 page views in June 2013. A comparison of the Breast Cancer Awareness Month page views in October 2012 and October 2013 shows a 1.2-fold increase in page views in October 2013 as compared with October 2012 (6,678 vs. 3,049 page views).

The number of page views of NCI's BRCA1 and BRCA2: Cancer Risk and Genetic Testing fact sheet (Figure 1b) in May 2013 was fivefold higher than the peak seen for the previous Breast Cancer Awareness Month in October 2012. The number of page views for this fact sheet in October 2013 was 82\% higher than the number of page views seen in October 2012.

Page views for the PDQ Genetics of Breast and Ovarian Cancer summary (Figure 1c) increased from an average of 6,121 monthly page views from January 2012 to April 2013 to 8,401 monthly page views from June to December 2013, reflecting a $37 \%$ increase over the longer term. Furthermore, a comparison of October 2012 with October 2013 reveals a 27\% increase in page views from one year to the next.

\section{Referral sources}

In the weeks preceding Jolie's op-ed piece, most viewers ( $\sim 80 \%)$ of the NCI breast cancer resources examined in this study came from search engines (Table 3). On two of the three Tuesdays preceding Jolie's op-ed piece, $0 \%$ of the online referrals to these resources were from news outlets via links included in news stories. However, on 14 May, nearly half of all referrals (49\%) to the breast cancer resources came directly from news outlets. Of these referrals, $81 \%$ were from traditional news outlets such as The New York Times, Forbes, and CNN, whereas 6\% were from celebrity news outlets such as People and Jezebel. One week later, on $21 \mathrm{May}, 11 \%$ of the referrals were still from news outlets. In the following weeks, the proportion of referrals from news outlets waned and returned to close to the level before
Jolie's op-ed piece, with only $1 \%$ of referrals attributable to news outlets on 25 June 2013.

Figure 2 presents the proportion of referrals to each of the breast cancer resources that can be attributed to search engines, news outlets, or other websites. News outlets had the largest effect on referrals to the Preventive Mastectomy fact sheet. On 23 April (not shown), 30 April, and 7 May, news outlets comprised $0 \%$ of the referral sources. On 14 May, however, $86 \%$ of the referrals were from news outlets. News outlets remained a prominent referral source in the weeks that followed, accounting for more than half of the referrals on 21 May (52\%) and 28 May (54\%) and accounting for $44 \%$ of the referrals on 4 June. Although this proportion decreased in the following weeks, it still accounted for $21 \%$ of source referrals on 25 June, 6 weeks after Jolie's op-ed piece.

The BRCA1 and BRCA2: Cancer Risk and Genetic Testing fact sheet and the PDQ Genetics of Breast and Ovarian Cancer summary each received a smaller percentage of referrals from news outlets on 14 May ( $4 \%$ and $14 \%$ of total daily referrals for each resource, respectively).

The Breast Reconstruction After Mastectomy fact sheet received no referrals from news outlets during the 10 days studied within the 9-week time period. Search engines comprised the majority $(78-86 \%)$ of referrals to this fact sheet on each of the dates studied.

\section{DISCUSSION}

The effect of Angelina Jolie's disclosure on information-seeking behavior was dramatic and immediate, with a high impact on Internet traffic to NCI's online resources. Our findings are consistent with previous observations of information seeking after other celebrity health-related disclosures. ${ }^{16-23}$ A study at NCI found a $400 \%$ increase in colon cancer inquiries to the Cancer Information Service after the 1985 announcement that a portion of President Ronald Reagan's colon had been removed. ${ }^{22}$ A decade later, researchers in the United Kingdom observed a $64 \%$ increase in breast cancer-related calls to CancerBACUP, the country's national cancer information service, after the

Table 3 Referrals to NCl breast cancer resources, April-June 2013

\begin{tabular}{|c|c|c|c|c|c|c|c|c|c|c|}
\hline & 23 April & 30 April & 7 May & 14 May $^{a}$ & 21 May & 28 May & 4 June & 11 June & 18 June & 25 June \\
\hline $\begin{array}{l}\text { Search } \\
\text { engines }\end{array}$ & $\begin{array}{l}1,751 \\
(83 \%)\end{array}$ & $\begin{array}{l}1,872 \\
(75 \%)\end{array}$ & $\begin{array}{l}1,691 \\
(84 \%)\end{array}$ & $\begin{array}{c}49,255 \\
(39 \%)\end{array}$ & $\begin{array}{l}3874 \\
(67 \%)\end{array}$ & $\begin{array}{l}2,705 \\
(70 \%)\end{array}$ & $\begin{array}{l}2,157 \\
(74 \%)\end{array}$ & $\begin{array}{l}1,762 \\
(76 \%)\end{array}$ & $\begin{array}{l}1,877 \\
(79 \%)\end{array}$ & $\begin{array}{l}1,715 \\
(78 \%)\end{array}$ \\
\hline $\begin{array}{l}\text { News } \\
\text { outlets }^{b}\end{array}$ & $\begin{array}{c}1 \\
(0 \%)\end{array}$ & $\begin{array}{c}266 \\
(11 \%)\end{array}$ & $\begin{array}{c}8 \\
(0 \%)\end{array}$ & $\begin{array}{c}61,444 \\
(49 \%)\end{array}$ & $\begin{array}{c}624 \\
(11 \%)\end{array}$ & $\begin{array}{l}257 \\
(7 \%)\end{array}$ & $\begin{array}{l}138 \\
(5 \%)\end{array}$ & $\begin{array}{c}76 \\
(3 \%)\end{array}$ & $\begin{array}{c}81 \\
(3 \%)\end{array}$ & $\begin{array}{c}27 \\
(1 \%)\end{array}$ \\
\hline Other ${ }^{c}$ & $\begin{array}{c}367 \\
(17 \%)\end{array}$ & $\begin{array}{c}375 \\
(15 \%)\end{array}$ & $\begin{array}{c}319 \\
(16 \%)\end{array}$ & $\begin{array}{l}15,909 \\
(13 \%)\end{array}$ & $\begin{array}{l}1,324 \\
(23 \%)\end{array}$ & $\begin{array}{c}898 \\
(23 \%)\end{array}$ & $\begin{array}{c}617 \\
(21 \%)\end{array}$ & $\begin{array}{c}471 \\
(20 \%)\end{array}$ & $\begin{array}{c}433 \\
(18 \%)\end{array}$ & $\begin{array}{c}457 \\
(21 \%)\end{array}$ \\
\hline $\begin{array}{l}\text { Total } \\
\text { referrals }\end{array}$ & $\begin{array}{c}2,119 \\
(100 \%)\end{array}$ & $\begin{array}{c}2,513 \\
(100 \%)\end{array}$ & $\begin{array}{c}2,019 \\
(100 \%)\end{array}$ & $\begin{array}{l}126,608 \\
(100 \%)\end{array}$ & $\begin{array}{c}5,822 \\
(100 \%)\end{array}$ & $\begin{array}{c}3,860 \\
(100 \%)\end{array}$ & $\begin{array}{c}2,912 \\
(100 \%)\end{array}$ & $\begin{array}{c}2,309 \\
(100 \%)\end{array}$ & $\begin{array}{c}2,391 \\
(100 \%)\end{array}$ & $\begin{array}{c}2,200 \\
(100 \%)\end{array}$ \\
\hline
\end{tabular}

Referral data were captured and reported for viewers who came to $\mathrm{NCI}$ breast cancer resources from sources other than the main $\mathrm{NCI}$ website, www.cancer.gov. $\mathrm{NCI}$ breast cancer resources included Preventive Mastectomy fact sheet, BRCA1 and BRCA2: Cancer Risk and Genetic Testing fact sheet, Breast Reconstruction After Mastectomy fact sheet, and PDQ Genetics of Breast and Ovarian Cancer summary.

$\mathrm{NCl}$, National Cancer Institute; PDQ, Physician Data Query.

aAngelina Jolie's op-ed piece, "My Medical Choice," was published in The New York Times. "News outlets include the following: The New York Times, China Times, CNN, Forbes, PBS, US News \& World Report, NPR, Chicago Tribune, Washington Post, MSN, National Geographic, Global Post, Fox, Sun-Sentinel, The Oregonian, Business Insider, The Guardian, Natural Health News, Times of Israel, CBS News, USA Today, NBC News, Huffington Post, LA Times, Bloomberg News, People, Jezebel, Wet Paint, The Blaze, The Examiner, Boston Magazine, The Wire, and Extra. 'Other referral sources include other NCI websites, typed URLs, bookmarked links, and other websites. 

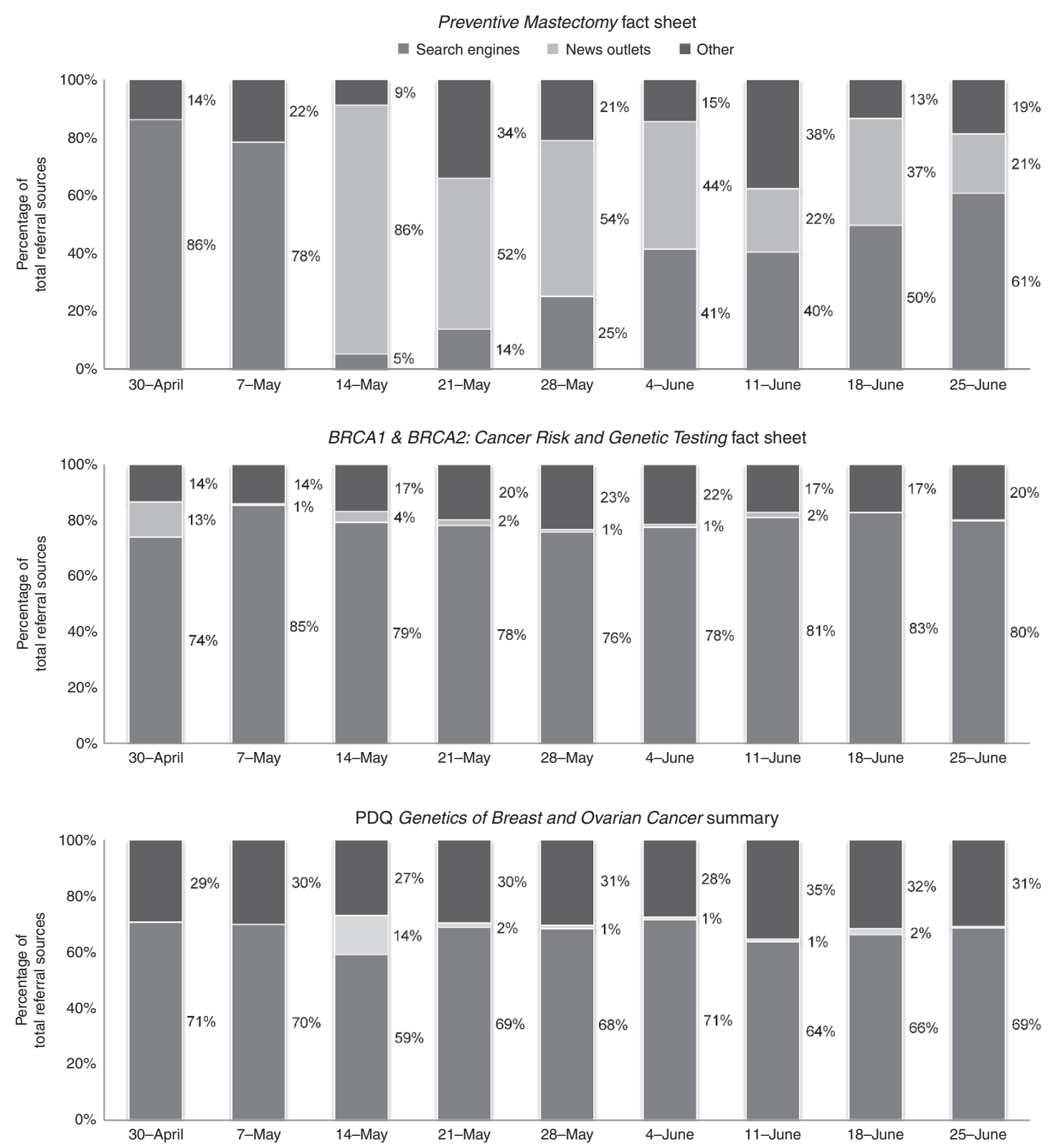

Breast Reconstruction After Mastectomy fact sheet

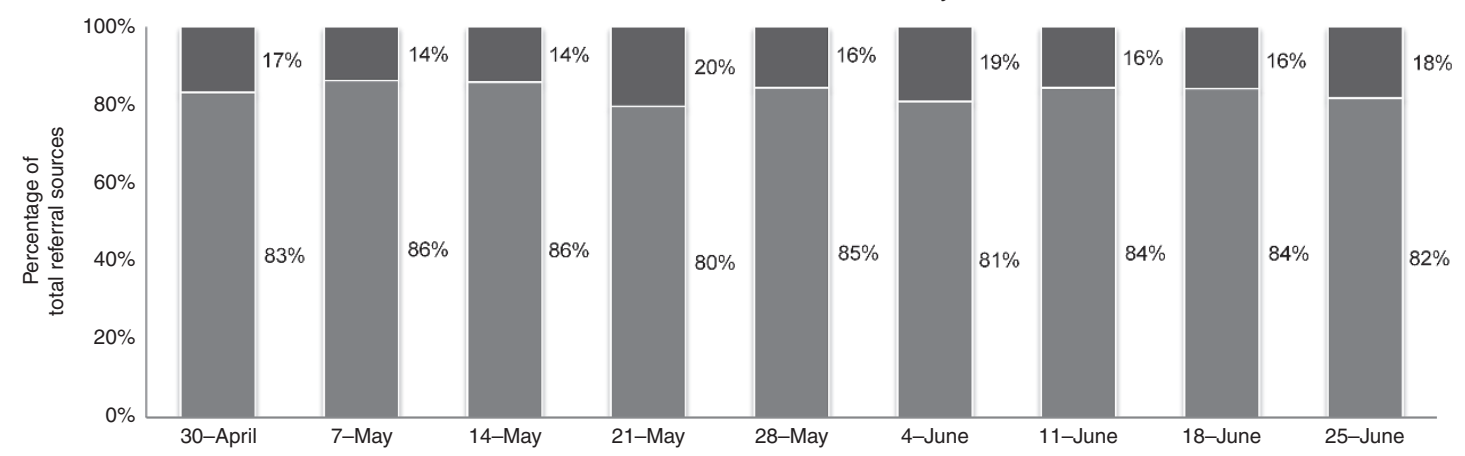

Figure 2 Referral sources to National Cancer Institute (NCI) breast cancer resources from 30 April 2013 through 25 June 2013 , including three fact sheets for the public (Preventive Mastectomy, BRCA1 and BRCA2: Cancer Risk and Genetic Testing, and Breast Reconstruction After Mastectomy) and one summary for health professionals (Physician Data Query (PDQ) Genetics of Breast and Ovarian Cancer). Websites of news outlets account for a large portion of the referrals to NCI's Preventive Mastectomy fact sheet on 14 May 2013. 
death of Linda McCartney, wife of singer Paul McCartney, from breast cancer. ${ }^{23}$ In an analysis of Internet search queries related to pancreatic cancer from 2006 to 2011, the cancer diagnosis of actor Patrick Swayze and the death of Apple Computer cofounder and CEO Steve Jobs were associated with pancreatic cancer search query increases of 285 and $197 \%$, respectively. ${ }^{29}$

In this study, we observed a profound effect on Internet traffic to NCI's cancer genetics and risk reduction resources, most notably the Preventive Mastectomy fact sheet, after the publication of Jolie's op-ed piece on 14 May 2013. This is consistent with a Google Trends analysis that identified a spike in online searches for mastectomy on 14 May and a similar increase in Internet traffic to the Wikipedia article on mastectomy. ${ }^{28}$ Online conversation about BRCA (on news websites, forums, blogs, and Twitter) also increased, although to a lesser extent, on the day Jolie's op-ed piece appeared. ${ }^{28}$

Both resources written for the general public and those for health professionals experienced a spike in Internet traffic in our study. As such, Jolie's op-ed piece may have had an impact on the information-seeking behaviors of health providers attempting to learn more about BRCA1 and BRCA2. ${ }^{30,31}$ Our study results support anecdotal evidence to date of increased calls to clinics by providers who had not previously referred patients for genetic counseling, ${ }^{12}$ highlighting the potential for celebrity announcements to have a significant impact on both public and provider behaviors.

Our study suggests that Jolie's disclosure generated a spillover effect on traffic to other NCI cancer genetics resources, including those specific to other cancer sites. This suggests that the effect of a celebrity's disclosure can be far-reaching and extend beyond the scope of the specific disease or procedure reported in the news. It is possible that people who came to the NCI website originally for information related to breast cancer or $B R C A$ viewed other resources on the site.

Our findings reveal important insights into the timing and long-term trends of individuals seeking this online information. Specifically, page views of NCI's breast cancer information were higher in October 2013 than in October 2012, which may reflect residual effects of Jolie's disclosure, either through greater public awareness of the topic or through continued mentions of the famous star during Breast Cancer Awareness Month.

On 14 May, $86 \%$ of all referrals to the Preventive Mastectomy fact sheet were from news outlets, suggesting that readers of news articles about Jolie were highly motivated to learn more about the procedure and followed links from the articles to do so. The New York Times accounted for the majority (78\%) of referrals to this fact sheet on 14 May (Jolie's op-ed piece included a link to the fact sheet); however, we observed 5,546 referrals from other news outlets. There were no referrals from news outlets to this fact sheet on the previous Tuesday. Notably, 2 weeks before Jolie's disclosure (30 April), we observed another example of a celebrity's announcement affecting referral traffic to NCI's breast cancer resources. Figure 2 shows $13 \%$ of referrals to the BRCA1 and BRCA2: Cancer Risk and Genetic Testing fact sheet were from news outlets on 30 April. On the same day,
American singer-songwriter Kara DioGuardi revealed in People her BRCA2 mutation status and her decision to have a child via a gestational surrogate. All of the referrals from news outlets on 30 April were from people.com; similar to Jolie's op-ed piece, the article about DioGuardi on people.com included a direct link to the fact sheet. Each of these examples illustrates the public's readiness to seek additional information after learning of a celebrity-related health issue by following direct links from news articles.

The findings of this study have implications for genetics professionals and other health-care providers who educate others about inherited disease risk and risk management. More broadly, it also has implications for organizations that aim to provide disease-specific information to the public. Jolie's disclosure has been regarded as a "teachable moment," with experts citing the need to communicate accurate and timely information about $B R C A$ gene mutations, their associated cancer risks, and available preventive options in the wake of her announcement. ${ }^{32}$ Some have suggested that the media fell short of this after Jolie's op-ed piece. ${ }^{32-34}$ For example, one study reported that the media failed to emphasize the rarity of Jolie's condition. ${ }^{34}$ Another study found that awareness of Jolie's disclosure was not associated with an improvement in the understanding of breast cancer risk. ${ }^{33}$ To facilitate access to accurate and comprehensive information about inherited conditions such as Jolie's, it may be beneficial for genetics professionals to work with journalists when events such as a celebrity diagnosis draw attention to an inherited condition. Our findings suggest that news referrals to educational content are an effective means to link the public to accurate information online. As such, collaboration between journalists and genetics professionals could effectively harness the star power of a celebrity such as Jolie while ensuring that people obtain appropriate resources designed to educate the public about the specific condition.

In addition to collaborating with journalists, genetic professionals can use clinical encounters as an opportunity to further educate patients about credible sources of online health information to which they can turn. Our findings demonstrated a nearly immediate increase in information seeking after Jolie's announcement; thus, organizations may wish to prepare themselves to educate the public at the time of a celebrity health episode by having an inventory of available resources to assist them in acting expeditiously to disseminate related messages and refer journalists and social media followers to appropriate information. In addition, health agencies may wish to consider innovative methods ${ }^{35}$ or multiple communication channels by which to reach their potential audience.

This is one of the first empirical studies to quantify the effect of Jolie's disclosure on information-seeking behavior. ${ }^{28}$ Strengths of this study include the scope and reach of the resources examined and its duration, with observations focused on both the immediate and long-term impact of a celebrity disclosure. Our data reveal important trends that demonstrate not only the effect of Jolie's disclosure on information seeking but also the influence of another celebrity and the impact of national 
campaigns surrounding Breast Cancer Awareness Month on Internet traffic to NCI's breast cancer resources.

This study has several limitations. We have no knowledge of who is accessing the information; they could be health professionals, patients, journalists, or other members of the public. We did not perform an analysis of unique visitors; therefore, we do not know whether the number of page views is representative of the number of individuals who viewed these resources or whether individuals accessed more than one resource. Moreover, although the increased page views during October 2013 versus October 2012 may be a result of residual attention related to Jolie, other historical trends could have contributed to the increase in Internet traffic over time. Finally, we were unable to capture referral information for individuals who used a typed or bookmarked link to access these resources, who navigated to the resources using a link from outside their Web browser (e.g., from an e-mail client), or who navigated to the resources from another NCI website. For these reasons, the "other referrals" category in our study is broad.

Additional studies are warranted to determine whether there is a relationship between Jolie's disclosure and cancer prevention and screening behaviors, as has been observed after other celebrity announcements. ${ }^{16,20-22,29}$ Future research might also strive to systematically quantify the increase in referrals for genetic testing and genetic counseling after Jolie's announcement.

In summary, celebrity disclosures, such as Jolie's revelation of her BRCA status and her prophylactic mastectomy decision, can dramatically influence online information-seeking behaviors, which may have further downstream effects on screening behaviors and disease outcomes. Genetics professionals can capitalize on these disclosures to ensure easy access to accurate information, which can help raise awareness, clarify misconceptions, and increase the likelihood of appropriate preventive actions to reduce disease risk.

\section{ACKNOWLEDGMENTS}

This study was completed as part of R.H.J.'s official duties at the National Cancer Institute, together with A.Z. (a contractor for the National Cancer Institute employed by iDoxSolutions) and C.W. (a member of the PDQ Cancer Genetics Editorial Board employed by Boston University). C.W. was funded by NCI K07 CA131103. We thank Margaret Beckwith, Rebecca Chasan, and Richard Manrow for their thoughtful review of the manuscript.

\section{DISCLOSURE}

The authors declare no conflict of interest.

\section{REFERENCES}

1. Jolie A. My medical choice. The New York Times 14 May 2013.

2. Burstein HJ. Lou Gehrig, Angelina Jolie, and cancer genetics. J Nat/ Compr Canc Netw 2013;11:631-632.

3. James PA, Mitchell G, Bogwitz M, Lindeman GJ. The Angelina Jolie effect. Med J Aust 2013;199:646.

4. Wax E, Sun LH. Angelina Jolie's mastectomy spotlights breast cancer, treatment options. The Washington Post, 2013. http://www.washingtonpost.com/ lifestyle/style/angelina-jolies-double-mastectomy-and-what-that-means-forcancer-diagnoses/2013/05/14/0eaef124-bcb9-11e2-89c9-3be8095fe767_ story.html. Accessed 07 April 2014.

5. Andrews $\mathrm{H}$, Heil E. What Angelina Jolie's double mastectomy means to breast cancer advocates. The Washington Post, 2013. http://www.washingtonpost. com/blogs/reliable-source/wp/2013/05/14/what-angelina-jolies-doublemastectomy-means-to-breast-cancer-advocates/. Accessed 06 April 2014.

6. Cotliar S. Angelina Jolie's double mastectomy: what to know about the 'faulty' gene. People, 2013. http://www.people.com/people/article/0,20700754,00. html. Accessed 6 April 2014.

7. Hurley R. Angelina Jolie's double mastectomy and the question of who owns our genes. BMJ 2013;346:f3340.

8. Kotz D. Increase in breast cancer gene screening: the Angelina Jolie effect. The Boston Globe, 2013. http://www.boston.com/lifestyle/health/blogs/dailydose/2013/12/03/increase-breast-cancer-gene-screening-the-angelina-jolieeffect/2HsXjeZh6MdTE5B8T3nGMl/blog.html. Accessed 7 April 2014.

9. 'Angelina Jolie effect' sparks surge in genetic testing. CBC News, 2013. http:// www.cbc.ca/news/canada/nova-scotia/angelina-jolie-effect-sparks-surge-ingenetic-testing-1.2101587. Accessed 6 April 2014.

10. 'Angelina Effect' sees referrals to cancer genetic clinics double. The Australian Hospital and Healthcare Bulletin, 2013. http://www.hospitalhealth.com.au/ news/health/angelina-effect-sees-referrals-cancer-genetic-clinics-double/. Accessed 7 April 2014

11. Lydall R. Angelina Jolie effect has doubled hospital breast cancer checks. London Evening Standard, 2013. http://www.standard.co.uk/news/health/ angelina-jolie-effect-has-doubled-hospital-breast-cancer-checks-8659187. html. Accessed 7 April 2014.

12. Nisker J. A public health education initiative for women with a family history of breast/ovarian cancer: why did it take Angelina Jolie? J Obstet Gynaecol Canada 2013:35:689-694.

13. O'Leary C. Jolie effect clogs cancer services. The West Australian, 2013. http:// au.news.yahoo.com/a/18026217/jolie-effect-clogs-cancer-services/. Accessed 7 April 2014.

14. Stokes K. Angelina effect having huge impact on SA women as genetic testing referrals for breast cancer triple. Herald Sun, 2013. http://www. heraldsun.com.au/news/national/angelina-effect-having-huge-impacton-sa-women-as-genetic-testing-referrals-for-breast-cancer-triple/storyfnii5yv7-1226729551932. Accessed 7 April 2014.

15. McPherson L. Angelina Jolie effect: Doctors plead for extra funding as they prepare for surge in genetic testing requests. Daily Record, 2013. http://www. dailyrecord.co.uk/news/health/angelina-jolie-effect-doctors-plead-1896942. Accessed 7 April 2014

16. Chapman S, McLeod K, Wakefield M, Holding S. Impact of news of celebrity illness on breast cancer screening: Kylie Minogue's breast cancer diagnosis. Med J Aust 2005; 183:247-250.

17. Casey GM, Morris B, Burnell M, Parberry A, Singh N, Rosenthal AN Celebrities and screening: a measurable impact on high-grade cervical neoplasia diagnosis from the 'Jade Goody effect' in the UK. Br J Cancer 2013;109:1192-1197.

18. Ayers JW, Althouse BM, Noar SM, Cohen JE. Do celebrity cancer diagnoses promote primary cancer prevention? Prev Med 2014;58:81-84.

19. Metcalfe D, Price C, Powell J. Media coverage and public reaction to a celebrity cancer diagnosis. J Public Health (Oxf) 2011;33:80-85.

20. Smith DP, Clements MS, Wakefield MA, Chapman S. Impact of Australian celebrity diagnoses on prostate cancer screening. Med J Aust 2009;191:574-575.

21. Lancucki L, Sasieni P, Patnick J, Day TJ, Vessey MP. The impact of Jade Goody's diagnosis and death on the NHS Cervical Screening Programme. J Med Screen 2012;19:89-93.

22. Brown ML, Potosky AL. The presidential effect: the public health response to media coverage about Ronald Reagan's colon cancer episode. Public Opin Q 1990;54:317-329.

23. Boudioni M, Mossman J, Jones AL, Leydon G, McPherson K. Celebrity's death from cancer resulted in increased calls to CancerBACUP. BMJ 1998;317:1016.

24. Noar SM, Willoughby JF, Myrick JG, Brown J. Public figure announcements about cancer and opportunities for cancer communication: a review and research agenda. Health Commun 2014;29:445-461.

25. Haglage A. I'm 25 and I have the Angie gene. The Daily Beast, 2013. http:// www.thedailybeast.com/articles/2013/05/15/i-m-25-and-i-have-the-angiegene.html. Accessed 6 April 2014.

26. Kluger J, Park A. The Angelina effect. Time 2013;181:28-33. 
27. Lee J. Celebrity impact: benefits, risks seen in hype over Jolie's disclosure. Modern Healthcare 2013:10-11.

28. Reid B. The 'Angelina Effect' in four charts. Huffington Post, 2013. http://www. huffingtonpost.com/brian-reid/angelina-jolie-double-mastectomy_b_3354589. html. Accessed on 6 April, 2014.

29. Noar SM, Ribisl KM, Althouse BM, Willoughby JF, Ayers JW. Using digital surveillance to examine the impact of public figure pancreatic cancer announcements on media and search query outcomes. J Natl Cancer Inst Monogr 2013;2013:188-194.

30. Bellcross CA, Leadbetter S, Alford SH, Peipins LA. Prevalence and healthcare actions of women in a large health system with a family history meeting the 2005 USPSTF recommendation for BRCA genetic counseling referral. Cancer Epidemiol Biomarkers Prev 2013;22:728-735.
31. Mouchawar J, Klein CE, Mullineaux L. Colorado family physicians' knowledge of hereditary breast cancer and related practice. J Cancer Educ 2001;16:33-37.

32. Schmidt C. Honing the health message on BRCA mutations. I Natl Cancer Inst 2013;105:1843-1844.

33. Borzekowski DL, Guan Y, Smith KC, Erby LH, Roter DL. The Angelina effect: immediate reach, grasp, and impact of going public. Genet Med 2014;16:516521.

34. Kamenova K, Reshef A, Caulfield T. Angelina Jolie's faulty gene: newspaper coverage of a celebrity's preventive bilateral mastectomy in Canada, the United States, and the United Kingdom. Genet Med 2014;16:522-528.

35. Cooper CP, Gelb CA, Vaughn AN, Smuland J, Hughes AG, Hawkins NA. Directing the public to evidence-based online content. J Am Med Inform Assoc 2014; e-pub ahead of print 22 July 2014. 